\title{
Comparative Study of Seli-Transcendence, Spiritual Well-Being, Optimism And Meaning In Life Among Retirees And Post-Retirement Employees
}

\section{Ayman Abdelgaalil M. Elkady, PhD}

Assistant Professor, Psychology Department, Faculty

of Arts, Tanta University, Egypt.

Psychology Department, College of Education, Jazan

University, Kingdom of Saudi Arabia.

Contact: E-mail: Ayman.elkady@gmail.com 



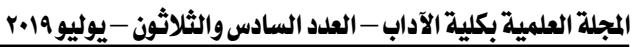

\section{Abstract}

The purpose of this study was to investigate the intercorrelations of self-transcendence, spiritual well-being, optimism and meaning in life. Additionally, the aim was to find out the differences in mean scores of self-transcendence, spiritual well-being, optimism and meaning in life between retirees and post-retirement employees. The sample consisted of people with Bachelor Degree. Retirees sample consisted of 60 participants (52 men, and 8 women), while postretirement employees consisted of 60 participants (all of them were men). The Self-Transcendence Scale (STS) (Reed, 2018), The Spirituality Index of Well-Being (SIWB) (Daaleman \& Frey, 2004), The Life Orientation Test-Revised (LOT-R) (Scheier, Carver \& Bridges, 1994) and Meaning in Life Questionnaire (Steger, Frazier, Oishi \& Kaler, 2006) were used. The data were analyzed with Pearson correlation. The t-test was used. Findings indicated that there were significant positive correlations between self-transcendence, spiritual well-being, optimism and meaning in life. Selftranscendence correlated positively with spiritual well-being, optimism, and meaning in life. Spiritual well-being correlated positively with optimism and meaning in life. There were differences in mean scores of self-transcendence, optimism and meaning in life between retirees and postretirement employees. However there was not difference in spiritual well-being between the two groups. Findings were discussed and conclusion was included.

Keywords: self-transcendence, spiritual well-being, optimism, meaning in life, retirees, post-retirement employees. 


\section{Introduction}

Work can be a resource of income and security. It provides people with behavioral confirmation through colleagues and supervisors. Work can help people deal with new tasks and developing skills through what is called stimulation (Wetzel, Huxhold, \& Tesch-Römer, 2016). One can presume that work is more than securing economic support; work is an important element in one's life that involves important psychological and social aspects that extend beyond basic needs (Fasbender, Wang, Voltmer, \& Deller, 2016). However, if the amount of money paid is low, if the person feels insecure, receives low approval and exposed to strenuous working conditions, this may be stressful (Wetzel et al., 2016). Retirement from work is a milestone and marks the end of working life. Retirement can be considered as a dramatic change of social status as well as transition from "worker" to "retired", which affects all domains of life (Çınar, Denizli, \& Cakir, 2014). Although retirement may promote a sense of well-being of workers moving out of demanding and/or stressful career jobs, this process may also involve distancing the person both psychologically and behaviorally from the workforce. This in turn exposes new social roles, expectations, challenges, and opportunities, on the person and all of which can influence well-being (Wang \& Shi, 2014). Post-retirement employment can be conceptualized as a developmental stage in one's (the retiree) late career (ibid, 2014). This important stage in one's life may include part-time jobs and self-employment (Beehr \& Bennett, 2015).

Self-transcendence is regarded as purpose in one's life and can be described as one's awareness of something or other people other than oneself (Sharpnack, Quinn Griffin, Benders, \& Fitzpatrick, 2011). It was found to provide hope 
which helps a person adapt and cope with life obstacles. Through self-transcendence, one can find meaning in life. Reed (2003) described self-transcendence as the capacity to ascend one's personal needs and desires and connect with others, their environment, and a spiritual dimension or God (Sharpnack et al., 2011). Sharing wisdom, integrating the aging process, accepting death as a part of life, and finding a spiritual meaning in life, all of which express selftranscendence (Reed, 2003). The correlation between spiritual well-being and self- transcendence has not been previously examined in retirees and in -service public employees.

Well-being is seen as a sense of feeling whole and healthy and is an outcome of self-transcendence (Sharpnack et al.,2011). Spiritual well-being can be regarded as the impact of spirituality, a sense of meaning, purpose, or power within a transcendent source, on subjective well-being (Daaleman, Perera, \& Studenski, 2004) Spirituality has great impact on and importance to well-being in the lives of elderlies as it can lead to or be predictor of overall satisfaction (Haugan, Rannestad, Hammervold, Garåsen, \& Espnes, 2014). Self-transcendence becomes evident through spirituality which is regarded as a human pattern (Sharpnack et al., 2011). It was found that spirituality was an effective variable in the overall well-being as well as in the quality of life (Beery, Baas, Fowler \& Allen, 2002). Therefore, the purpose of this study was to examine the relationship between self-transcendence and spiritual well-being as well as the differences between retirees and in -service public employees.

Optimism is seen as positive expectations about one's own future. Optimism was found to be positively correlated with employee performance (Mishra, Patnaik \& Mishra, 
2016). It can be presume that those with high levels of optimism tend to expect good things to happen to them, anticipate positive results and success in challenging individual tasks. According to results of Chhajer, Rose, and Joseph (2018), optimism is effective since those in -service employees who are supposed to be high on optimism maintain positive expectation and believe they will succeed regardless of their abilities. Optimism was found to influence successful exits from the world of work (Topa, Alcover, Moriano \& Depolo, 2014) and would affect retirement adjustment quality (Topa \& Inmaculada, 2018).

How people comprehend, make sense of, or see significance in their lives is a simple definition of meaning in life as well as the degree to which those people have a purpose, mission, or over-arching aim in life (Krause \& Hayward, 2014). Those authors (Krause \& Hayward, 2014) proposed a model composed of five factors of meaning in life; the first factor is one's own values, which are considered to be norms that describe desirable behaviors and beliefs. The second is a sense of purpose, that is, the affective evaluation that the person has after successful implementing; those behaviors which are consistent with one's values. The third comprises goals people seek to achieve investing their energy, efforts and ambitions. Reconciling the past is the fourth factor. The feeling that life makes sense is the fifth factor. It means the ability to explain the events in one's life, as well as others 'behaviors and one's own actions.

\section{Problem Statement}

Work is thought of as a central aspect of our lives, where it enables workers to feel happier, hopeful, optimistic and be more punctual. Meanwhile, retirement is supposed to be a major transition in the life of eldest people. According to research studies (Hershey, Henkens \& van Dalen, 2010; 
Peiró, Tordera \& Potocnik, 2013); employees, when they come to retire, are concerned with financial aspects and quality of life. Moreover, social, affective and family bonds are markedly mattered (Kubicek, Korunka, Raymo \& Hoonakker, 2011; Antonucci, 2001).

\section{This study poses the following questions:}

1-Are there relationships between and among selftranscendence, spiritual well-being, optimism and meaning in life?

2- Is there significant difference in self-transcendence between retirees and post-retirement employees?

3- Is there significant difference in spiritual well-being between retirees and post-retirement employees?

4- Is there significant difference in optimism between retirees and post-retirement employees?

5- Is there significant difference in meaning in life between retirees and post-retirement employees?

\section{Significance of the study}

This study could contribute to the literature on selftranscendence, spiritual well-being, optimism and meaning in life among retirees and post-retirement employees. The study is concerned with retirees and post-retirement employees and presents some factors, namely self-transcendence, spiritual well-being, optimism and meaning in life that might contribute to and have impact on both retirees and postretirement employees.

\section{Hypotheses}

Hypothesis (1): There are positive correlations between and among self-transcendence, spiritual well-being, optimism and meaning in life.

Hypothesis (2): There would not be significant difference in self-transcendence between retirees and post-retirement employees. 
Hypothesis (3): There would not be significant difference in spiritual well-being between retirees and post-retirement employees.

Hypothesis (4): There would not be significant difference in optimism between retirees and post-retirement employees.

Hypothesis (5): There would not be significant difference in meaning in life between retirees and post-retirement employees.

\section{Method}

\section{Design}

The researcher has adopted a descriptive research design to describe and compare self-transcendence, spiritual wellbeing, optimism and meaning in life among retirees and postretirement employees.

\section{Participants}

The participants were sampled using purposive sampling technique. They were typical cases that provided requisite data or information. In this regard, the researcher identified actual population of interest (retirees and post-retirement employees). The sample consisted of people with Bachelor Degree. Retirees sample (those who no longer hold jobs) consisted of 60 participants (52 men, and 8 women), while post-retirement employees (those who hold jobs after retirement) consisted of 60 participants (all of them were men). They aged from $61-66(\mathrm{M}=62.3$ years, $\mathrm{SD}=1.12)$. The marital status was as follows: married $=110$, widow $=10$. They were from Water Resource Company $(n=6)$, Electricity Company $(n=3)$, Ministry Of Agriculture $(n=10)$, Ministry of Local Government $(n=14)$ and Ministry of Education $(n=87)$. 


\section{Instruments:}

The Self-Transcendence Scale (STS) (Reed, 2018). A 15 items, one-dimensional, 4-point Likert scale from 1 (never) to 4 (always). The intention was to identify intrapersonal, interpersonal, transpersonal, and temporal experiences characteristic of later life, which reflect expanded boundaries of self (Reed, 2018). The Scale was translated into Arabic and translated back into English. The back-translated version was reviewed and approved by a panel of three assistant professors in English department. The scale scores range from 15 to 60 (from 1 to 4 for each item), and the high scores indicate a high self-transcendence. The internal consistency of the scale was measured through Cronbach's alpha estimated at 0.91 . The content validity of the scale was examined by a group of 10 experts. They assessed the relevance of each item using a four-point Likert scale (where 1 represents "irrelevant" and 4 represents "highly relevant"). They provided suggestions and comments. The 15 items were judged to be quite or highly relevant. A content validity index was calculated at the item level $(\mathrm{I}-\mathrm{CVI}=0.90)$.

The Spirituality Index of Well-Being (SIWB) (Daaleman \& Frey, 2004). A 12 items, 5-point Likert scale ranging from "strongly agree" to "strongly disagree". The intention was to measure well-being within the context of spirituality. The final score of the scale is obtained by adding those of each item and then dividing by number of items each respondent answer to obtain a mean score. The scale scores range from 12 to 60 (from 1 to 5 for each item), and high scores are indicative of high levels of spirituality well-being. The Scale was translated into Arabic and translated back into English. The backtranslated version was reviewed and approved by a panel of three assistant professors in English department. In this study, reliability was calculated by using t-retest after 14 days . 
Correlation coefficient was 0.688 for the whole scale. For convergent validity of The Spirituality Index of Well-Being (SIWB), correlation with Religious Orientation Questionnaire (Adawi, 2015) was significant $(\mathrm{r}=0.62, \mathrm{p}<.01)$.

The Life Orientation Test-Revised (LOT-R) (Scheier, Carver, \& Bridges, 1994). A widely used, unidimensional, 10 items, 5-point Likert dispositional optimism scale. Respondents rate each item on a 4-point scale: $0=$ strongly disagree, 1 = disagree, $2=$ neutral, $3=$ agree, and $4=$ strongly agree. The final score of the scale is obtained by summing the items' scores after reverse-scoring the negative items (items 3, 7, and 9) and eliminating the four filler items (items 2, 5, 6, and 8). Computed scores are on ranged from 0 to 24 where high scores are indicative of high levels of optimism. The Scale was translated into Arabic and translated back into English. The back-translated version was reviewed and approved by a panel of three assistant professors in English department. . In this study, The reliability of the scale in terms of internal consistency was assessed by Cronbach's $\alpha$. $(\alpha=0.72)$.For convergent validity of The Life Orientation Test-Revised (LOT-R), correlation with Optimism Scale (Eid, Mahmoud \& Farag, 2015) was significant $(r=0.60, \mathrm{p}<.01)$.

Meaning in Life Questionnaire (Steger, Frazier, Oishi \& Kaler, 2006). A 10-item, 7-point Likert-type scale ranging from 1 (Absolutely True) to 7 (Absolutely Untrue). The intention was to assess the presence of, and search for, meaning in life. Computed scores are on ranged from 10 to 70. The Scale was translated into Arabic and translated back into English. The back-translated version was reviewed and approved by a panel of three assistant professors in English department. The reliability of the scale in terms of internal consistency was assessed by Cronbach's $\alpha$. $(\alpha=0.82)$. The 
split half reliability index for the ten MLQ items was Spearman-Brown Coefficient (equal and unequal length) $=.69$ and Guttman Coefficient $=.68$. For convergent validity of Meaning in Life Questionnaire, correlation with The Five Factor Scale of Resilience (Hamid, 2010) was significant $(r=0.63, p<.01)$.

\section{Ethical Considerations}

Retirees and post-retirement employees voluntarily participated in the study. They were free to discontinue responding to the questionnaires or in the study as a whole at any time. The researcher explained verbally about the study purposes privately before obtaining consent from each retiree and post-retirement employee. Information collected in the study was kept strictly confidential, concealed, and it was used strictly for the purposes of this study. Sure, there were neither known risks for participating in this study nor any incentives provided for participation.

\section{Procedures}

Prior to administering the scales, retirees and postretirement employees were informed about purpose of the study and voluntarily stated that they accept to participate to the study. To ensure that the respondents responded to the items honestly and sincerely, they were told not to identify themselves in any way on the scale paper. They were also informed that they should not be concerned with anything concerning their participation in the study and their responses are for research purposes only and would be kept confidential. Each questionnaire took about 10-15 minutes to complete .Data were entered in Excel and SPSS files.

\section{Data Analysis}

The data were analyzed with Pearson correlation. The ttest was used to explore the differences in self-transcendence, spiritual well-being, optimism and meaning in life among retirees and post-retirement employees. 


\section{Results}

Descriptive data and inter-correlations

Table (1) shows the means, descriptive statistics and intercorrelations of self-transcendence, spiritual well-being, optimism and meaning in life. Table (1) shows that there are significant positive correlations between self-transcendence, spiritual well-being, optimism and meaning in life. Selftranscendence correlates positively with spiritual well-being $(r=0.542)$, optimism $(\mathrm{r}=0.508)$ and meaning in life $(\mathrm{r}=$ 0.443). Spiritual well-being correlates positively with optimism $(r=0.514)$ and meaning in life $(r=0.455)$.

Table 1 - Descriptive statistics and inter-correlations

of self-transcendence, spiritual well-being, optimism and meaning in life

\begin{tabular}{|c|c|c|c|c|}
\hline \hline Variables & $\begin{array}{c}\text { self-transce- } \\
\text { ndence }\end{array}$ & $\begin{array}{c}\text { Spirit-ual well- } \\
\text { being }\end{array}$ & $\begin{array}{c}\text { Optim- } \\
\text { ism }\end{array}$ & $\begin{array}{c}\text { meaning in } \\
\text { life }\end{array}$ \\
\hline self-transcendence & 1.00 & $0.542^{* *}$ & $0.508^{* *}$ & $0.443^{* *}$ \\
\hline spiritual well-being & $0.542^{* *}$ & 1.00 & $0.514^{* *}$ & $0.455^{* *}$ \\
\hline optimism & $0.508^{* *}$ & $0.514^{* *}$ & 1.00 & $0.520^{* *}$ \\
\hline meaning in life & $0.443^{* *}$ & $0.455^{* *}$ & $0.520^{* *}$ & 1.00 \\
\hline Mean & 35.591 & 45.125 & 12.750 & 33.125 \\
\hline Standard deviation & 10.059 & 5.453 & 4.106 & 11.007 \\
\hline$* * \mathrm{P}<.01$ & & & & \\
\hline \hline
\end{tabular}

The difference in self-transcendence

Table (2) shows the t-test results for the differences in mean scores of self-transcendence between retirees and postretirement employees.

The table shows that (t) vale was (3.027). This value is significant at the level $(\mathrm{p}<0.01)$ in the favor of the postretirement employees. 
Table 2 - The t-test results for the differences in mean scores of self-transcendence between retirees and post-retirement employees

\begin{tabular}{|c|c|c|c|c|c|}
\hline \hline Group & $\mathrm{N}$ & Mean & SD & $\mathrm{T}$ & Sig. \\
\hline \hline retirees & 60 & 40.616 & 9.010 & \multirow{2}{*}{3.027} & 0.01 \\
\hline $\begin{array}{c}\text { post-retirement } \\
\text { employees }\end{array}$ & 60 & 44.866 & 5.321 & \\
\hline \hline
\end{tabular}

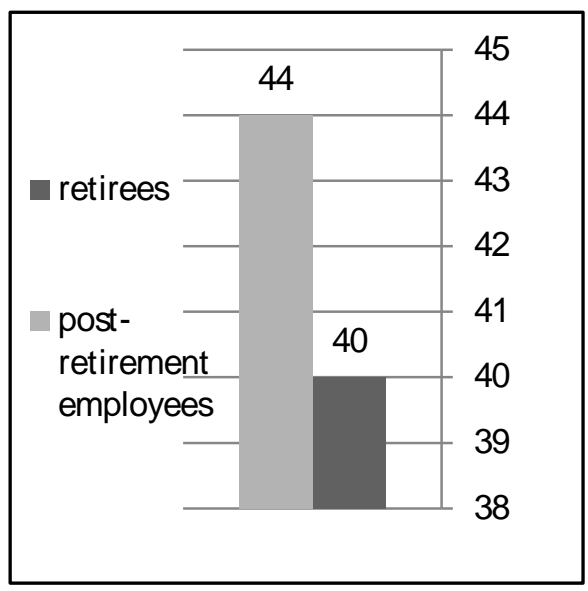

Figure 1 - The differences in mean scores of self-transcendence between retirees and Post-retirement employees

The difference in spiritual well-being

Table (3) shows the t-test results for the differences in mean scores of spiritual well-being between retirees and postretirement employees. The table shows that $(\mathrm{t})$ vale was (0.977). This value is not significant. This means that there are no differences between retirees and post-retirement employees groups in spiritual well-being. 
Table 3 - The t-test results for the differences in mean scores of spiritual well-being between retirees and post-retirement employees

\begin{tabular}{|c|c|c|c|c|c|}
\hline \hline Group & $N$ & Mean & $S D$ & $T$ & Sig. \\
\hline \hline retirees & 60 & 45.116 & 5.437 & & Not \\
\hline $\begin{array}{c}\text { post-retirement } \\
\text { employees }\end{array}$ & 60 & 45.133 & 5.515 & 0.977 & \\
\hline \hline
\end{tabular}

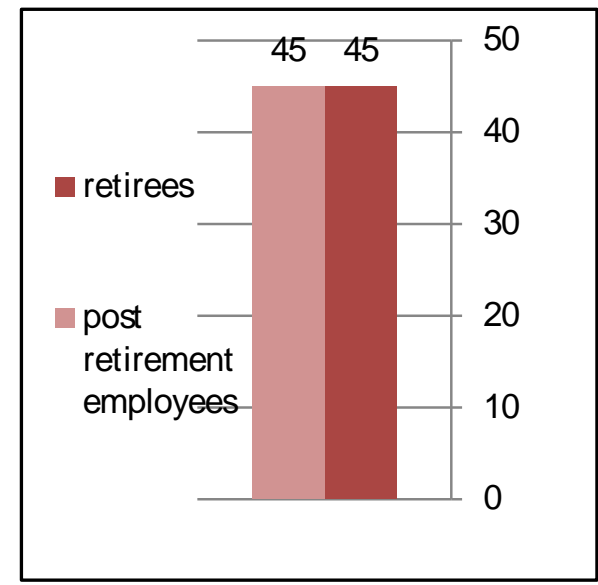

Figure 2 - The differences in mean scores of spiritual wellbeing between retirees and post-retirement employees The difference in optimism

Table (4) shows the t-test results for the differences in mean scores of optimism between retirees and post-retirement employees. The table shows that (t) vale was (5.700). This value is significant at the level $(p<0.01)$ in the favor of the post-retirement employees. 
Table 4 - The t-test results for the differences in mean scores of optimism between retirees and post-retirement employees

\begin{tabular}{|c|c|c|c|c|c|}
\hline \hline Group & $N$ & Mean & SD & $T$ & Sig. \\
\hline \hline retirees & 60 & 12.400 & 4.592 & \multirow{2}{*}{5.700} & 0.01 \\
\hline $\begin{array}{c}\text { post-retirement } \\
\text { employees }\end{array}$ & 60 & 16.300 & 2.644 & \\
\hline \hline
\end{tabular}



Figure 3 - The differences in mean scores of optimism between retirees and post-retirement employees

The difference in meaning in life

Table (5) - shows the t-test results for the differences in mean scores of optimism between retirees and post-retirement employees. The table shows that $(\mathrm{t})$ vale was $(2.437)$. This value is significant at the level $(\mathrm{p}<0.01)$ in the favor of the post-retirement employees. 
Table 5 - The t-test results for the differences in mean scores of meaning in life between retirees and postretirement employees

\begin{tabular}{|c|c|c|c|c|c|}
\hline \hline Group & $N$ & Mean & $S D$ & $T$ & Sig. \\
\hline \hline retirees & 60 & 36.016 & 13.609 & & \\
\hline $\begin{array}{c}\text { post-retirement } \\
\text { employees }\end{array}$ & 60 & 42.550 & 12.943 & 2.437 & 0.01 \\
\hline \hline
\end{tabular}

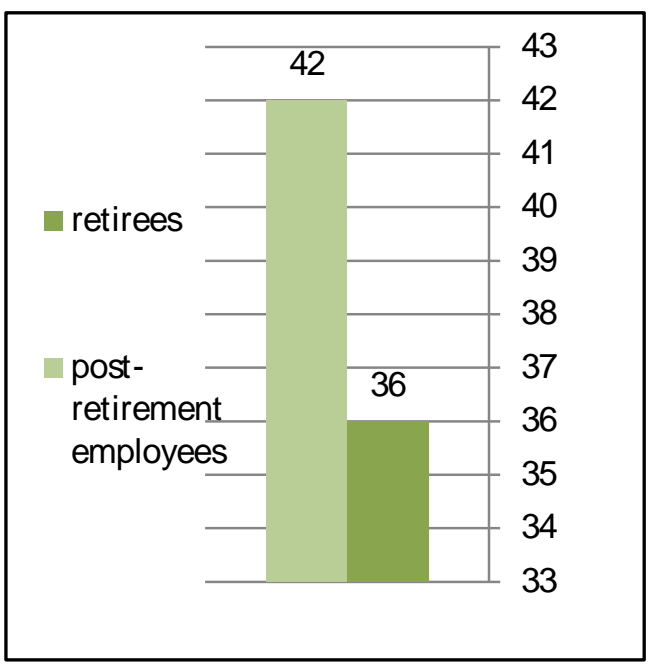

Figure 4 - The differences in mean scores of meaning in life between retirees and

\section{Discussion}

\section{post-retirement employees}

The purpose of this study was to investigate the intercorrelations of self-transcendence, spiritual well-being, optimism and meaning in life. Additionally, the aim was to find out the differences in mean scores of self-transcendence, spiritual well-being, optimism and meaning in life between retirees and post-retirement employees.

Results, as shown in table (1) indicated that there were significant positive correlations between self-transcendence, spiritual well-being, optimism and meaning in life. Selftranscendence correlated positively with spiritual well-being, 
optimism and meaning in life. Spiritual well-being correlated positively with optimism and meaning in life.

Spirituality is a particularly important factor to general well-being in the lives of people who retired from work and those who continued to work post-retirement. Selftranscendence can be described as a powerful coping mechanism that helps people adapt to physical, emotional and spiritual distress (Teixeira, 2008). Self-transcendence addresses an enhanced understanding of well-being in those who continued to work post-retirement (Reed, 2018). Spiritual concept lies at the heart of self-transcendence. This concept looks at the true meaning of life (ibid, 2018).

People by nature strive to find meaning and purpose in life through self-transcendence. Self-transcendence is regarded as a process of achieving changes in one's live through which one strives for new and deeper understandings of life, meaning, and acceptance of the self, others and the life situation (Haugan, Moksnes, \& Løhre, A., 2016).

Meaning in life and spiritual well-being can be achieved through one's relationships and connectedness with others, by communication with those who are around him/her, and his/ her ability to self-reflect on responsibilities. Spirituality is regarded as a personal effort to understand the meaning in life and its goal (Haugan et al., 2014; Adib-Hajbaghery \& Faraji, 2015).

Results, as shown in table (2) indicated that there were differences in mean scores of self-transcendence between retirees and post-retirement employees. Self-transcendence, which is the ability to expand one's relationship with others and the environment, provides hope and meaning, but sometimes some retirees cannot cope with the lose of work through retirement. However, some other people can cope with the lose of work through retirement and search for work. 
This new work broadens their relationship with others and the environment (Reed, 2018). This self-transcendence shapes post-retirement employees' perspectives on self, others, the nature of this world, and of a dimension beyond the here and now (McCarthy, Bowland, Hall, \& Connelly, 2015). Self-transcendence helps retirees through personal growth, integration of present with past and future, and investing in personal relationships.

Results, as shown in table (3) indicated that there were no differences between retirees and post-retirement employees groups in spiritual well-being. Faith and belief in religion is an important part in our lives as Egyptians. Faith represents the religious component of spiritual well-being (Haugan et al., 2014). Faith in God and satisfaction in the judgment of God can be considered as a part of our faith. This can explained that those who were included as participants in this study, especially the retirees, had belief and faith in God so that this could be a buffering factor against feelings of loneliness and other psychological problems associated with retirement, or stop working. Spirituality includes vital quality of life resources such as hope, self-transcendence, and meaning (Haugan et al., 2016).

Results, as shown in table (4) indicated that there were differences in mean scores of optimism between retirees and post-retirement employees in the favor of the post-retirement employees. Optimism is positively related to employee performance (Mishra et al. 2016). Dispositional optimism can be regarded as a resource that keeps a positive mood, and can be a buffering factor against potential negative effects of retirement. People who are optimistic can easily adjust more favorably to life transitions. Those who engage in work after retirement have optimism about the future and hope to stay longer. They do not give in to retirement. Those who return 
to work after retirement expect positive outcomes and tend to see the best in a bad situation; they are likely to demonstrate more proactive coping behaviors (Reinhoudt, 2004).

Finally, results, as shown in table (5) indicated that there were differences in mean scores of meaning in life between retirees and post-retirement employees in the favor of the post-retirement employees. Meaning in life constitutes an important resource in later life stages. It can be said that work represents meaning for a specific life domain. People who experience transition to retirement lose their work-role as they are no longer workers, and work as a source of meaning disappears. This in turn has important implications in terms of meaning in life. Some people search for another meaning; that is meaning in life by continuing to work or engage in a new type of work. Through this new meaning in life, people comprehend, make sense of, or see significance in their lives (Steger, Oishi \& Kashdan, 2009).

\section{Conclusion}

In conclusion, the present study provided evidence that through self-transcendence, one can find meaning in life. Spirituality well- being is a particularly important factor to general well-being in the lives of people who retired from work and those who continued to work post-retirement. Meaning in life and spiritual well-being can be achieved through one's relationships and connectedness with others, by communication with those who are around him/her, and his/ her ability to self-reflect on responsibilities. Dispositional optimism can be regarded as a resource that keeps a positive mood, and can be a buffering factor against potential negative effects of retirement. Those who engage in work after retirement and are high on optimism believe they will succeed regardless of their abilities. 


\section{References}

Adawi, Taha (2015). Self-concept and its relationship to religious orientation and psychological hardiness in university students. Journal Psychological Counseling, 2015, 42: 143-182.

Adib-Hajbaghery, M., \& Faraji, M. (2015). Comparison of Happiness and Spiritual Well-Being among the Community Dwelling Elderly and those who Lived in Sanitariums. International Journal of Community Based Nursing and Midwifery, 3(3), 216-226.

Antonucci, T. (2001). Social relations: an examination of social networks, social support, and sense of control. In J. E. Birren \& K. W. Schaie (Eds.), Handbook of the psychology of aging (pp. 427-453). San Diego: Academic Press.

Beehr, T. A., \& Bennett, M. M. (2015). Working after retirement: Features of bridge employment and research directions. Work, Aging and Retirement, 1, 112-128.

Beery, T. A., Baas, L. S., Fowler, C., \& Allen, G. (2002). Spirituality in persons with heart failure. Journal of Holistic Nursing, 20 (1), 5-25.

Chhajer, R., Rose, E. L., \& Joseph, T. (2018). Role of Selfefficacy, Optimism and Job Engagement in Positive Change : Evidence from the Middle East. The Journal for Decision Makers, 43(4), 222-235.

Çınar, E., Denizli, U., \& Cakir, Ö. (2014). Phenomenon of working after retirement and its relation with quality of life in Turkey. European Journal of Research on Education. 2(2), 45-54.

Daaleman, T., \& Frey, B. (2004). The Spirituality Index of Well-Being: A New Instrument for Health-Related Qualityof-Life Research. The Annals of Family Medicine, 2(5), 499503. 
Daaleman, T., Perera, S., \& Studenski, S. (2004). Religion, spirituality, and health status in geriatric outpatients. The Annals of Family Medicine, 2(1), 49-53.

Eid, M., Mahmoud, H., \& Farag, S. (2015). Psychometric properties of optimism. Journal of Psychological Counseling, 44, 537-558.

Fasbender, U., Wang, M., Voltmer, J., \& Deller, J. (2016). The Meaning of Work for Post-retirement Employment Decisions. Work, Aging and Retirement, 2(1), 12-23.

Hamid, Mohammed S. (2010). Psychometric Characteristics of Resilience Scale among University students. Journal of college of education, 34(2), 539-573.

Haugan, G., Moksnes, U., \& Løhre, A. (2016). Intrapersonal self-transcendence, meaning-in-life and nurse-patient interaction: powerful assets for quality of life in cognitively intact nursing-home patients. Scandinavian Journal of Caring Sciences, 30, 790-801.

Haugan, G., Rannestad, T., Hammervold, R., Garåsen, H., \& Espnes, G. (2014). The relationships between selftranscendence and spiritual well-being in cognitively intact nursing home patients. International journal of older people nursing, 9(1), 65-78.

Hershey, D. A., Henkens, K., \& Van Dalen, H. P. (2010). Aging and financial planning for retirement: interdisciplinary influences viewed through cross-cultural lens. International Journal of Aging \& Human Development, 70, 1-38.

http://rave.ohiolink.edu/etdc/view?acc_num=osu1092771722 Krause, N., \& Hayward, D. (2014). Assessing Stability and Change in a Second-Order Confirmatory Factor Model of Meaning in Life. Journal of Happiness Studies, 15, (2), 237-253. Kubicek, B., Korunka, C., Raymo, J. M., \& Hoonakker, P. (2011). Psychological well-being in retirement: The effects of personal and gendered contextual resources. Journal of Occupational Health Psychology, 16(2), 230-246. 
McCarthy, V., Bowland, S., Hall, L., \& Connelly, J. (2015). Assessing the Psychoeducational Approach to Transcendence and Health Program: An Intervention to Foster SelfTranscendence and Well-Being in Community-Dwelling Older Adults. The international journal of aging \& human development, 82(1), 3-29.

Mishra, U., Patnaik, S., \& Mishra, B. (2016). Role of optimism on employee performance and job satisfaction. Indian Journal of Management, 9(6), 35-46.

Peiró, J., Tordera, N., \& Potocnik. K. (2013). Retirement practices in different countries. In Wang, $\mathrm{M}$ (Ed.), The Oxford Handbook of Retirement (510-540). New York: Oxford university Press.

Reed, P. (2003). The theory of self-transcendence. In M. J. Smith \& P.R. Liehr (Eds.), Middle range theory for nursing (pp. 145-165). New York: Springer Publishing Company.

Reed, P.G. (2018). Theory of self-transcendence. In M.J.Smith \& P.R. Liehr (Eds.), Middle range theory for nursing (4th ed.) (pp. 119-146). New York: Springer Publishing Company.

Reinhoudt, C. J. (2004). Factors related to aging well: the influence of optimism, hardiness and spiritual well-being on the physical health functioning of older adults. Ph.D. thesis, Ohio State University. U.S.A. Permalink:

Scheier, M. F., Carver, C. S., \& Bridges, M. W. (1994). Distinguishing optimism from neuroticism (and trait anxiety, self-mastery, and self-esteem): a re-evaluation of the Life Orientation Test. Journal of Personality and Social Psychology, 67(6), 1063-1078.

Sharpnack, P. A., Quinn Griffin, M. T., Benders, A. M., \& Fitzpatrick, J. J. (2011). Self-Transcendence and Spiritual Well-Being in the Amish. Journal of Holistic Nursing, 29(2),91-97. 
Steger, M. F., Frazier, P., Oishi, S., \& Kaler, M. (2006). The meaning in life questionnaire: Assessing the presence of and search for meaning in life. Journal of Counseling Psychology, 53(1), 80-93.

Steger, M. F., Oishi, S., \& Kashdan, T. B. (2009). Meaning in life across the life span: Levels and correlates of meaning in life from emerging adulthood to older adulthood. The Journal of Positive Psychology, 4(1), 43-52.

Teixeira, M. (2008). Self-transcendence: A concept analysis for nursing praxis" Holistic nursing practice, 22(1), 25-31.

Topa, G. and Inmaculada P. (2018). Retirement Adjustment Quality: Optimism and Self-Efficacy as Antecedents of Resource Accumulation. Applied Research in Quality of Life, 13(4),1015-1035.

Topa, G., Alcover, C., Moriano, J., \& Depolo, M. (2014). Bridge employment quality and its impact on retirement adjustment: A structural equation model with SHARE panel data. Economic and Industrial Democracy, 35(2), 225-244.

Wang, M., \& Shi, J. (2014). Psychological research on retirement. Annual Review of Psychology, 65, 209- 233.

Wetzel, M., Huxhold, O., \& Tesch-Römer, C. (2016). Transition into retirement affects life satisfaction: Short- and long-term development depends on last labor market status and education. Social Indicators Research, 125 (3), 9911009. 


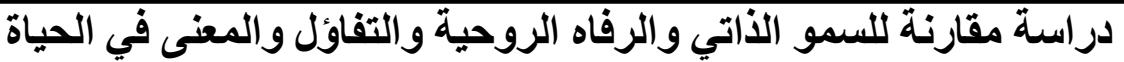

بين المتقاعدين وموظفي ما بعد التقاعد التئ

أيمن عبدالجليل محمد القاضي ماتئ

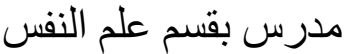

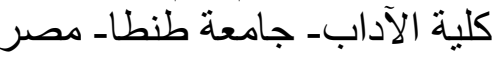

كلية التربية- جامعة جاز انــ السعودية

هدفت الدراسة الحالية الى دراسة العلاقات المتبادلة بين السمو الذاتي

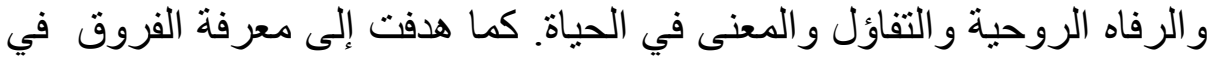

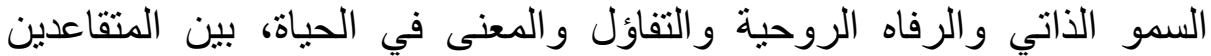

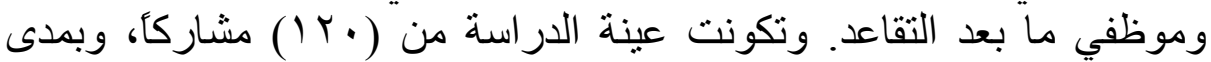

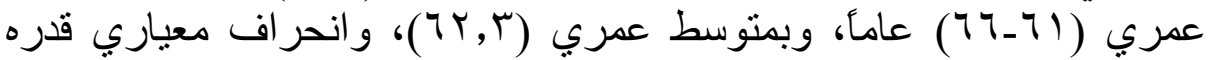

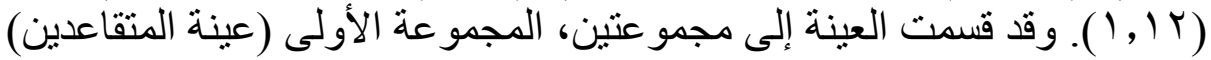

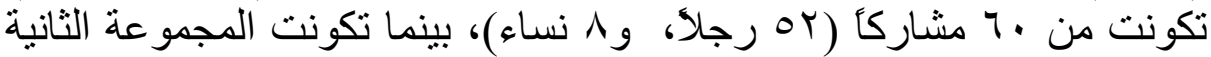

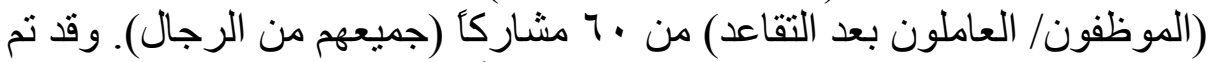

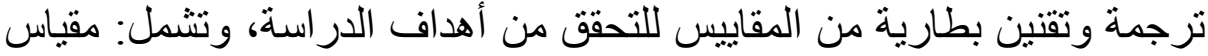

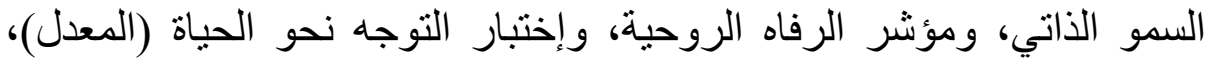


بيرسون، و اختبار "ت" للكثف عن دلالة الفروق بين المجمو عتين. وقد إنتهت نتائج الدراسة إلى وجود علاقات ارتباطية موجبة دالة دالة بين السين السمو الذاتي؛

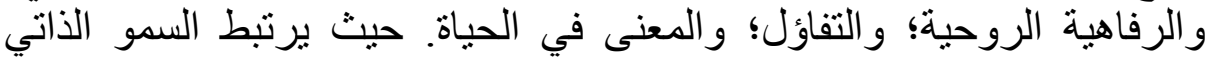

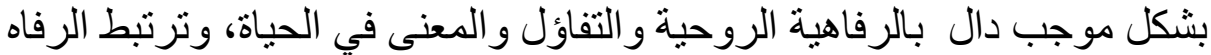

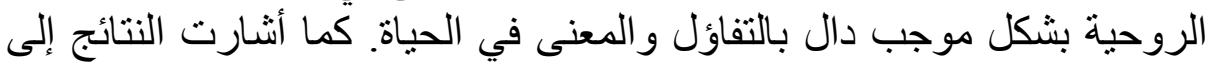

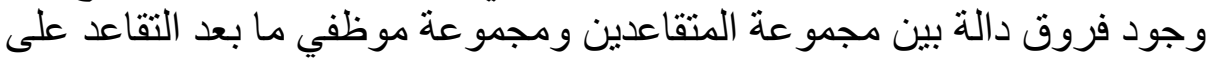

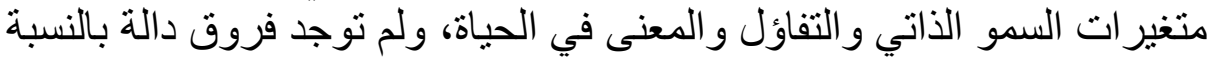
لمتغبر الرفاه الروحية بين المجمو عتين.

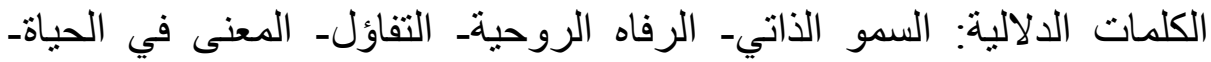
المتقاعدين- موظفي ما بعد التقاعد. التئ. 